\title{
Student-Centered Learning Environment for Disaster- Mitigating Engineering Design and Deployment in Developing Regions
}

\author{
Erica Catherine Gonzalez \\ Undergraduate Student, Department of Civil Engineering \\ Catholic University of America \\ Washington, DC 20064 \\ 05gonzae@cardinalmail.cua.edu \\ Evan Andrew Heisman \\ Undergraduate Student, Department of Civil Engineering \\ Catholic University of America \\ Washington, DC 20064 \\ 62heisman@cardinalmail.cua.edu \\ Gunnar Lucko, Ph.D. \\ Assistant Professor, Department of Civil Engineering \\ Catholic University of America \\ Washington, DC 20064 \\ lucko@cua.edu
}

\begin{abstract}
A comprehensive student-centered learning environment was created in a funded course sequence on disaster-mitigating design and practice at the Catholic University of America. This paper details educational issues related to accreditation outcomes, accommodation of instructional methods to different learning styles, and educational objectives based on Bloom's taxonomy. The focus of this educational effort was on exploring solutions for mitigating earthquake damage in developing regions, which suffer disproportionally high casualties. Undergraduate students were in charge from planning to implementation, including a critiqued literature review on socio-cultural environments and traditional technologies, evaluating low-cost damping systems in laboratory testing, preparing architectural designs per functional needs of its host community, performing structural calculations per the International Building Code, and coordinating its implementation. Faculty organized site visits and guest lectures and served as facilitators who contributed sessions on seismology, creativity, and entrepreneurship. Collaborating with local Engineers Without Borders chapters enabled two successful trips to a village of approximately 3,200 inhabitants located in rural El Salvador. The team assessed site conditions and built a new health clinic of reinforced masonry with concrete beams on rubber pad foundation dampers. The local community participated in planning and volunteered significant labor to "make the project their own." Recommendations are presented on implementing learning experiences that groom globally aware and socially engaged young engineers.
\end{abstract}

Index Terms - Developing regions, earthquake damages, low-cost building technologies, student-centered learning. 


\section{INTRODUCTION}

Interest in engineering service outreach at Catholic University of America (CUA) began with guest presentations by Peace Corps alumni and by the founder of Engineers Without Borders (EWB) on his vision of "building a better World, one community at a time" in order to satisfy basic human needs. Students founded a new EWB chapter. Members of the Department of Civil Engineering realized that the traditional course of study did not sufficiently prepare students for addressing engineering problems within a global context. A task group examined the feasible options and a course on sustainability ${ }^{1}$, international practices, and ethics was added to the curriculum. The EWB chapter has built an active membership and collaborated closely in this project with a host community in a developing region, Santa Clara in southeastern El Salvador.

\section{Need for Earthquake-Resistant Structures}

While Western news media often highlight the massive devastation by earthquakes for only a few weeks until other topics capture the public's attention, their effects are felt in the affected region for decades. Earthquakes larger than a moment magnitude of approximately 6.5 can cause thousands of casualties in developing regions and can cause billions of dollars worth of damages to their vulnerable built environment. Table I gives an overview of significant earthquakes that struck developing regions. Many others still caused severe damages but are omitted for brevity.

\section{TABLE I}

Impact of Recent Significant Earthquakes in Developing Regions, compiled from United States Geological Survey $^{8,9,10,11}$

\begin{tabular}{lllllll}
\hline Date & Region & Magnitude & Fatal & Injured & Displaced & Houses Destroyed or Damaged \\
\hline $1 / 12 / 10$ & Haiti & 7.0 & 222,570 & 300,000 & $1,300,000$ & $97,294 / 188,383$ \\
$9 / 30 / 09$ & Indonesia & 7.5 & 1,117 & 1,214 & 451,000 & 181,665 \\
$10 / 28 / 08$ & Pakistan & 6.4 & 169 & 370 & 120,000 & $3,487 / 4,125$ in Harnai area \\
$5 / 12 / 08$ & China & 7.9 & 87,587 & 374,177 & over & $5,360,000 / 21,000,000$ [sic], 2,473 \\
& & & & & $5,000,000$ & dams, \\
& & & & & & $53,000 \mathrm{~km}$ roads, 48,000 km water \\
& & & & & & pipes, $\$ 86 \mathrm{~B}$ \\
$8 / 7 / 07$ & Perú & 8.0 & 514 & 1,090 & - & 39,700 \\
$5 / 26 / 06$ & Indonesia & 6.3 & 5,749 & 38,568 & 600,000 & $578,000, \$ 3.1 \mathrm{~B}$ \\
$10 / 8 / 05$ & Pakistan & 7.6 & 87,350 & 75,266 & $4,000,000$ & over 32,355 in several municipalities \\
$3 / 28 / 05$ & Indonesia & 8.6 & 1,313 & 400 & - & 300 \\
$12 / 26 / 04$ & Indonesia & 9.1 & 227,898 & - & $1,700,000$ & fourth strongest since 1900, tsunami \\
& & & & & & affected 18 countries \\
$12 / 26 / 03$ & Iran & 6.6 & 31,000 & 30,000 & 75,600 & $85 \%$ in Bam area, $\$ 32.7 \mathrm{M}$ \\
$5 / 21+$ & Algeria & $6.8,5.8$ & 2,266 & 10,261 & 180,000 & $43,500, \$ 0.6 \mathrm{~B}$ to $\$ 5 \mathrm{~B}$ \\
$5 / 27 / 03$ & & & & & & \\
$3 / 25+$ & Afghanistan & $6.1,5.6$ & 1,000 & 100 's & 1,000 's & about 2,000 \\
$3 / 27 / 02$ & & & & & & \\
$1 / 26 / 01$ & India & 7.6 & 20,085 & 166,836 & - & $339,000 / 783,000$ \\
$1 / 13 / 01$ & El Salvador & 7.7 & 852 & 4,723 & - & over 258,226 \\
$11 / 12 / 99$ & Turkey & 7.1 & 894 & 4,948 & - & extensive \\
$9 / 20 / 99$ & Taiwan & 7.6 & 2,400 & 8,700 & 600,000 & $82,000, \$ 14 \mathrm{~B}$ \\
$8 / 17 / 99$ & Turkey & 7.6 & 17,118 & 50,000 & 500,000 & $\$ 6.5 \mathrm{~B}$
\end{tabular}




\begin{tabular}{lllllll}
\hline $1 / 25 / 99$ & Colombia & 6.1 & 1,885 & 4,750 & 250,000 & $50-60 \%$ in two municipalities \\
\hline
\end{tabular}

Region of where earthquake occurred may also include neighboring countries. Missing persons are listed as fatalities. The symbol - designates unknown data. All values are official estimates.

Earthquakes frequently strike developing regions with devastating consequences. Impacts of such disasters extend beyond immediate casualties to damaged or destroyed property, buildings, and infrastructure, which weaken the regional economy in the long term. The predominant traditional residences in many developing regions are mostly simple one and two-story adobe, rubble or brick masonry, or un-reinforced concrete block structures ${ }^{2,3,4,5,6}$ with loose clay tile roofs. This insufficient structural system places the houses at risk of failure in an earthquake. Adobe, in fact, increases in vulnerability from erosion during periodic wet seasons or flooding ${ }^{7}$.

The loss of human life and damaged or destroyed residential and commercial property and infrastructure can weaken the regional economy and threaten entire societies. Many developing regions are in fact located in the tectonically active areas of the Pacific Rim shown in Figure 1, which is called the "ring of fire" due to its significant concentration of volcanoes and seismic events around the Pacific and other major and minor tectonic plates that make up Earth's crust.

Designing a structure to be more resistant to earthquake loads, testing scaled models, and implementing a prototype of the final design under actual field conditions were the goals of the two-semester undergraduate course sequence that was developed at CUA, which was funded by an entrepreneurial grant of the National Collegiate Inventors and Innovators Alliance (NCIIA).

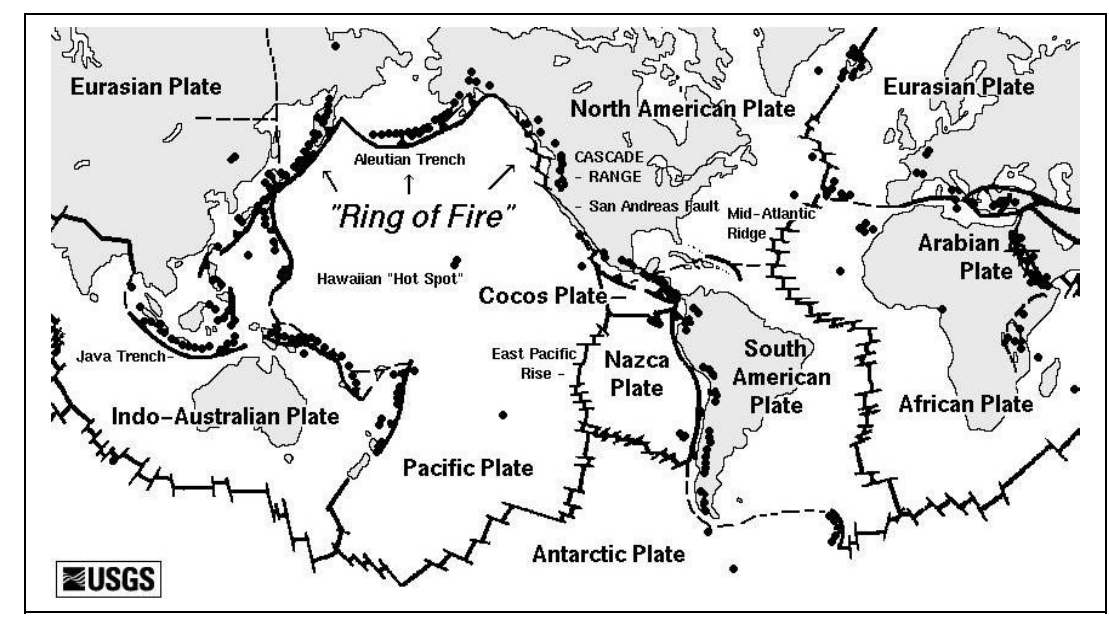

FIGURE 1

Tectonic Plates and Volcanoes, public domain image by United States Geological Survey / Cascades Volcano Observatory

\section{Integration with Educational Outcomes}

This need to explore solutions that improve the earthquake-resistance of such simple structures is an active area of research ${ }^{12,13}$, but has not yet been brought effectively into an educational context. This project sought to specifically address six of the eleven educational goals specified by the Accreditation Board for Engineering and Technology ${ }^{14}$ : 
(b) ... design and conduct experiments,... analyze and interpret data; (c) ... design a system, component, or process to meet desired needs within realistic constraints such as ... sustainability; (d) ... function on multi-disciplinary teams; (g) ... communicate effectively; (h) ... understand the impact ... in a global, economic, environmental, and societal context; and $(\mathrm{k})$... use the techniques, skills, and modern engineering tools.

\section{Need for Student-Centered Learning}

Recent changes in the accreditation requirements for engineering education place even more weight on the learning output in the student than on the teaching input by the faculty ${ }^{15}$. Other characteristics of this educational paradigm are an emphasis on teamwork and on project-based work that engineering graduates will invariably encounter upon entering the industry as well as instilling an appreciation of lifelong learning.

While not explicitly mentioned there, a closely related didactic philosophy has refined such an approach. Under the so-called student-centered learning the students have a significant amount of personal responsibility and the freedom to create their individual learning experiences to the extent that it may "initially be met with uncertainty and irritation" ${ }^{16}$. This pedagogy's successful educational contributions are well-documented in the literature ${ }^{17}$ and it is widely accepted as a highly effective educational approach.

Students who are participating in a student-centered learning program play an active role in developing their own processes and products to explore the subject matter at hand. Problem definition by the student is emphasized. The depth of understanding and appreciation for the material typically exceeds what traditional teaching may achieve. Faculty members assume the role of facilitators who set the scope, pose challenges, provide guidance, and are partners with the students during the learning process.

While it may at first appear less formal or unstructured, it is rich in opportunities for students to develop their own interests and styles. At the same time, faculty are challenged even more than in traditional teaching, as the lessons change from a monologue style to a constructive dialogue. This also poses a higher demand on utilizing assessment techniques for the student's original work rather than following one narrow prescribed format.

Project work ${ }^{18}$ is ideal for student-centered learning ${ }^{19}$. By targeting the need of a developing region, this project also has characteristics of service-learning ${ }^{20,21}$. Amadei et al. ${ }^{22}$ pioneered such active learning in service outreach to developing communities with a focus on sustainability and appropriate technology, which led to the founding of EWB. Sheppard et al. ${ }^{23}$ also called for project-based learning to address the challenges of a global society, e.g. natural disasters.

Overall, a need exists to educate globally aware and socially engaged young engineers who holistically consider technical, socio-economic, political, and cultural factors in designing and executing their projects:

\section{Bloom's TaXonomy of Learning}

In addition to addressing accreditation outcomes, the elements of this project were designed to follow all six competency levels of Bloom's taxonomy of educational objectives ${ }^{24}$ as listed in Table II. They range from simple acquisition of knowledge via its comprehension, application to new circumstances, analysis and interpretation of results, and their integrating synthesis, to the higher-level critical evaluation of new concepts. 
Every student has their own preferred personal learning style that may often differ from the predominant style used in traditional lectures. Early learning models focused on the human senses and which one dominates the intake of information, whether visual, auditory, tactile, or kinesthetic ${ }^{25}$.

\section{TABLE II}

Bloom's Taxonomy and Project Elements, adapted from Bloom ${ }^{26}$

\begin{tabular}{llll}
\hline $\begin{array}{l}\text { Lev } \\
\text { el }\end{array}$ & Competence & Instructional Activities & Project Elements \\
\hline 6 & Evaluation & Compare, critique, justify, optimize & $\begin{array}{l}\text { Host community feedback incorporation, } \\
\text { final detail design, progress evaluations }\end{array}$ \\
5 & Synthesis & Propose, formulate, create, design & $\begin{array}{l}\text { Performance specifications, functional } \\
\text { requirements, prototype concept design } \\
\text { Laboratory testing, business plan, review } \\
\text { of building code, structural calculations } \\
\text { Creativity techniques, conceptual design, } \\
\text { model fabrication, field implementation }\end{array}$ \\
4 & Analysis & Classify, arrange, derive, predict & $\begin{array}{l}\text { Literature reviews, damping system } \\
\text { whitepapers, presentations on regions } \\
\text { Seismology, traditional building } \\
\text { methods, socio-cultural environment }\end{array}$ \\
\hline
\end{tabular}

Modern approaches to understanding learning take a process-oriented view. Such integrated $\operatorname{model}^{27,28}$ includes input, perception, processing, and understanding as dimensions and two preferences for each. This project incorporated elements toward these different styles as listed in Table III to expose the students to a wide range of educational opportunities throughout it planning and execution.

TABLE III

\begin{tabular}{|c|c|c|}
\hline Dimension & $\begin{array}{l}\text { Preference } \\
\mathrm{S}\end{array}$ & Project Elements \\
\hline \multirow[t]{2}{*}{ Input } & Visual & Model fabrication, laboratory testing, site visits \\
\hline & Verbal & Guest presentations, presentations on regions \\
\hline \multirow[t]{2}{*}{ Perception } & Sensing & Model fabrication, laboratory testing, site visits \\
\hline & Intuitive & Creativity techniques, performance specifications \\
\hline \multirow[t]{2}{*}{ Processing } & Active & Creativity techniques, prototype concept design, final detail design \\
\hline & Reflective & Host community feedback incorporation, progress evaluations \\
\hline Understandin & Sequential & Seismology, review of building code, structural calculations \\
\hline $\mathrm{g}$ & Global & Traditional building methods, socio-cultural environment \\
\hline
\end{tabular}

\section{Core Participants}

Participants in this project formed an entrepreneurially oriented group as envisioned by the funding agency:

An E-Team is a multidisciplinary team of students, faculty, and industry mentors ..., who work together to bring a product or technology from idea to prototype to commercialization. The 
"E" stands for excellence and entrepreneurship... to develop sustainable technologies that help address issues of environmental degradation and meet basic human needs ${ }^{30}$.

The project was set up as an interdisciplinary two-semester course sequence "DisasterMitigating Design and Practice for the Developing World I and II" that was open to all undergraduate students in engineering and architecture as well as graduate students as a program elective. The E-Team, composed of students, their faculty, and several associated professionals, including recent graduates, developed a viable solution from conceptualization through research and development, models testing in the laboratory, and engineering design to its implementation in a village in a developing region. The effort satisfied the most fundamental level of Maslow's hierarchy of human needs ${ }^{31}$, shelter, and also - in its field implementation - basic healthcare.

The E-Team worked closely with the newly founded EWB student chapter. Many enrolled students were also members or officers of that interdisciplinary chapter at CUA. Contacts to the national organization and local professionals as well as to a Peace Corps volunteer who lived in the developing region were an invaluable resource in planning the trips to the host community.

\section{Supporting Project Elements}

Quality research and development work must be based on a thorough understanding of the literature and practice. To handle large amounts of material and efficiently and effectively extract valuable information from it the E-Team used several supporting elements as per Table IV.

\section{TABLE IV}

Additional Supporting Project Elements in Student-Centered Learning Environment

\begin{tabular}{ll}
\hline $\begin{array}{l}\text { Supporting project } \\
\text { elements }\end{array}$ & Description \\
\hline Materials reader & $\begin{array}{l}\text { Faculty compiled a reader containing a variety of introductory papers on traditional } \\
\text { housing, state of technology in developing regions, seismic events and their damages } \\
\text { and mitigation. This reader was used as a reference during discussions and design } \\
\text { sessions. Students particularly commented on its usefulness as a starting point to their } \\
\text { own inquiries and work on research and development. }\end{array}$ \\
All students were trained by a university librarian in essential scholarly skills, e.g. \\
catalog and database searches, document request and retrieval, and critical evaluation \\
in summarizing essays. Incidentally, one student was a library work-study and \\
facilitated deeper searches, e.g. patents. \\
The E-Team searched and retrieved various pertinent materials, including references to \\
this paper. All materials were labeled and housed in a central resource archive in the \\
course website software. \\
The E-Team set up a dedicated resource library for this project. It was stocked with \\
several dozen reference books that students could access in a departmental room. \\
Among the first assignments that the E-Team created for itself was the preparation of \\
summaries of the essential facts for these books as their related to this project, which \\
were posted to the aforementioned resource archive. \\
Various guests were invited for a broader contextual understanding. In this project \\
they included e.g. the thesis of an architecture graduate student on constructability of \\
flexible wall systems, a faculty on post-tensioned mortar-less masonry, use of bamboo, \\
and natural fiber reinforcements, and two alumnae on technical challenges and \\
personal experiences of volunteer work in Ecuador.
\end{tabular}




\section{Creativity Components}

A special component of this project was a creativity workshop for the entire E-Team. The corresponding author introduced various creativity techniques based on materials endorsed and published by the American Society for Engineering Education ${ }^{32}$. Table V lists the problem identification strategies, creativity concepts, solution generation, and evaluation techniques that the E-Team practiced. Several case studies that applied such principles were discussed. While a positive contribution of this workshop is difficult to measure due to lack of a control group, the authors feel that it opened students' minds to innovative thinking. Students later noted the value of this unusual educational unit, which was not part of any previous engineering courses at CUA.

TABLE V

Creativity Components, extracted from Fogler and LeBlanc ${ }^{33}$

\begin{tabular}{|c|c|}
\hline Component & Details \\
\hline $\begin{array}{l}\text { Problem } \\
\text { identificatio } \\
\mathrm{n}\end{array}$ & $\begin{array}{l}\text { Importance of defining real problem; distinguishing symptoms and causes; collecting and } \\
\text { structuring rich data; identifying key characteristics; developing a problem-solving attitude; } \\
\text { recognizing blockades to problem solving (including e.g. mental, perceptional, emotional, cultural, } \\
\text { environmental, intellectual, and expressive blocks) }\end{array}$ \\
\hline $\begin{array}{l}\text { Problem } \\
\text { abstraction }\end{array}$ & $\begin{array}{l}\text { Modeling and simulation; detailing versus simplification; inductive and deductive reasoning; } \\
\text { scenario exploration; heuristics as structured problem-solving approaches; paradigm shifts to } \\
\text { overcome fixed traditional approaches }\end{array}$ \\
\hline $\begin{array}{l}\text { Problem } \\
\text { solution }\end{array}$ & $\begin{array}{l}\text { Brainstorming and brainwriting the stream of consciousness and subsequent evaluation; Osborne's } \\
\text { checklist (including e.g. adaptation, modification, magnification, minification, substitution, } \\
\text { replacement, rearrangement, combination, etc. of elements); random stimulation with abstractions, } \\
\text { associations, and random word triggers; five-why technique to explore problems in-depth; five } \\
\text { questions technique for breadth; attribute listing; six thinking hats (including data, emotion, } \\
\text { judgement, positive, alternatives, and overview roles); futuring to overcome current technological } \\
\text { limitations and other constraints; associative diagramming for organizing and categorizing, e.g. } \\
\text { fishbone diagrams, mind mapping, and lotus blossoms; analogy and cross-fertilization thinking }\end{array}$ \\
\hline
\end{tabular}

\section{Entrepreneurial Element}

The entrepreneurial work of the E-Team was supported by a session on entrepreneurship and business plan development, including a feasibility analysis and financial forecasting. While the outcome of this project was a damping system implemented in a building and not a product for potential commercialization, e.g. a water cooker or grain crusher ${ }^{34}$, the students could still apply the knowledge and general principles from this element to their planning and analysis work.

\section{Regional Reports}

An important component of this project was that students researched and composed reports addressing various aspects of developing regions or countries. Four major geographic regions 
that are affected by earthquakes as shown in Figure 1 were selected: Central America, North America and the Near East, Southeast Asia, and South America. Within them, the E-Team selected countries (El Salvador, Guatemala, Algeria, Morocco, Iran, Indonesia, Myanmar, Ecuador, Chile, and Perú) for further study. This socio-cultural analysis reviewed the society of the respective regions in terms of education and literacy, health, urban and rural population, dwelling types, occupancy patterns, infrastructure, cultural, political, and economic influences, topography and geology, natural resources, climate, and, naturally, its seismology. To address an accreditation criterion, each presentation was annotated, critiqued, and discussed by the E-Team. It was rated on a 5-point Likert scale on its structure, clarity in communicating the topic, strength of supporting data, interacting with the audience, quality of visual aids and handout, and overall performance. Interestingly, the students were more critical than their faculty on several of these criteria. The E-Team then ranked the developing regions based on broad factors including seismic hazard, structural vulnerability, population vulnerability, area accessibility, political stability, and existing projects. The E-Team thus narrowed the scope of its subsequent work to just one developing region and the specific country of El Salvador.

\section{Seismology and Earthquake Engineering Lectures}

A set of five lectures introducing seismology and earthquake engineering were prepared by coinvestigator Dr. Tsopelas to provide the E-Team with a solid foundation for their research, development, and design work. Important topics that were introduced were seismology, including geological fundamentals, plate tectonics, and elastic rebound theory, characterization of earthquakes by epicenter, intensity, magnitude, and energy, and seismic statistics, (b) ground motion parameters, i.e. amplitude, frequency content, and duration, wave types, propagation and attenuation, site effects, and design motions, and (c) soil-structure-interaction, foundation and structural responses, and (d) risk analysis as a combination of location hazards and structural performance. These presentations were enhanced by case studies of earthquakes and their effects in various developing regions with a comparison of their differences due to local soil conditions and structural types. The E-Team was then familiarized with the Structural Control and Aseismic Research (SCARE) earthquake laboratory at CUA with a load testing apparatus and its so-called shake table shown in Figure 2. This $2.5 \mathrm{~m}$ by $1.5 \mathrm{~m}$ unidirectional seismic simulator can create sinusoidal, white noise, random, and seismic excitation with a maximum acceleration of $1.5 \mathrm{~g}$.

Due to the real-time sensing and computational requirements of active dampers and their prohibitive costs in new or retrofitted structures, the E-Team decided for focus this project only on passive damping systems, which are low-maintenance and low-cost, e.g. do not need actuators, computer, and energy source, but incur the tradeoff of possibly reduced efficiency.

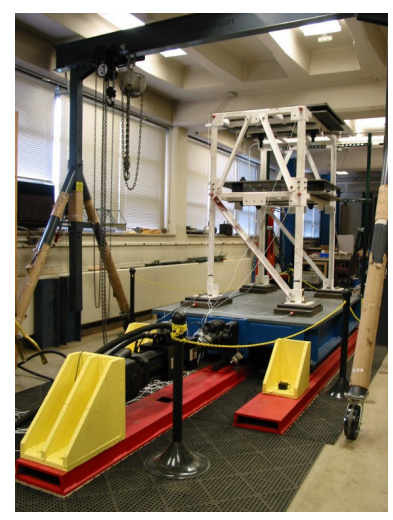




\title{
FIGURE 2
}

\author{
Seismic Simulator (Courtesy of Dr. Panagiotis Tsopelas)
}

\section{Creative Initial Development}

A previous study examined low-cost materials to mitigate or prevent earthquake damages in Turkey ${ }^{35,36,37}$. Strips cut off car tires, a recyclable material, were installed as stabilizing belts in otherwise unreinforced masonry walls. The E-Team found that this approach, while bearing significant merit, suffers from being a secondary mitigation that dissipates energy once it has already entered the structure, but does not eliminate is as a primary barrier at the foundation itself. Another study ${ }^{38,39}$ used squares or strips cut from car tires to assemble foundation dampers with or without steel plate inlays. A number of related patents were identified. Data sheets for rubberized materials were obtained from tire manufacturers and the literature was searched on long-term load-bearing capacity ${ }^{40}$, especially considering creep, i.e. its slow deformations under long load. One study offered a simulation of ground tire rubber mixed with soil and discussed its challenges ${ }^{41}$. Other technical systems include springs, rollers or ball bearings, and rockers ${ }^{42}$.

Using these inspirations the E-Team brainstormed on using whole used tires in a regular grid pattern underneath a floor slab to seismically isolate the building from the soil, which was pioneered by $\mathrm{Nguyen}^{43}$, and which could be filled with sand or gravel or left unfilled ${ }^{44}$. The ETeam considered implementation, e.g. lifting a separately cast slab on top of tires, or casting concrete onto a lost formwork overlay, e.g. a membrane, or imprinting tires into the fresh concrete. The latter advantage is the indentations locking the tires more solidly into place against sideways motion. Interestingly, since then other researchers have used layering of whole tires to protect a structure against a nearby demolition blast ${ }^{45}$. The availability of this recycling material and potential to reduce waste in landfills led the E-Team to collect data on the load-bearing and deformation behavior of rubber and the toroidal geometry and inner composition of tires, while ignoring treads due to their interrupted surface and variable depth of abrasion.

Numerous Asian studies worked on sand cushions as passive dampers for foundations ${ }^{46,47,48 \text {, }}$ 49, 50 and even for museum exhibits ${ }^{51}$. Kinetic energy is dissipated by friction into shear deformation and heat. Such approach is viable due to its low cost, abundantly available material, ease of manufacturing and installation, and long service duration. Variations of the granular materials and the encapsulation, a sturdy membrane of fabric or rubber, and its shape are possible. The E-Team discussed the questions of longevity of a membrane, closing it by wire (as in sandbags for flood protection), heat-sealing, or other methods, and the stress distribution with a faculty in geotechnical engineering, who provided data on the behavior of granular materials. Foregoing the membrane for a sand pit with a synthetic liner is another option ${ }^{52}$, but could be challenging due to the precisely aligned curvature that has to be constructed underneath the pit.

Two less obvious solutions that were created through the brainstorming process of the ETeam were tensegrity structures, i.e. frames structural elements that alternatingly are in tension and compression, but may apply more to temporary structures and require pivoting connections, and electromagnetic or hydraulic dampers that due to their required energy supply and expensive components did not fulfill the E-Team's criterion of low-cost solutions. 
Secondary mitigation systems that are used in adobe structures, e.g. natural fibers, wooden bracing, or even chicken wire ${ }^{53,54,55}$ provide a moderate degree of protection against cracking, but they fell short against the foundation dampers in the cost-benefit comparison of the E-Team.

\section{Whitepaper Presentation}

The E-Team created a whitepaper process to prepare its further work, wherein the students wrote, presented, and discussed a possible solution based on the previously acquired literature and newly developed analytical techniques, including the previously discussed tire insulators, sand cushions, tensegrity structures, and electromagnetic or hydraulic dampers. The whitepapers consisted of refining a solution idea into a detailed two-page executive summary of its approach, theoretical background, a drawing, an evaluation of advantages and disadvantages, conclusions, and references. The whitepapers were the basis of further development and laboratory testing.

\section{Laboratory Testing}

Due to the space limitations of this paper the technical details of prototype design and the laboratory testing will be discussed in an abbreviated form. A separate session on experimental research design introduced the essential concepts of research hypotheses, randomization, sampling, randomization, statistical data analysis, and verification and validation methods that the E-Team subsequently incorporated into the laboratory work. The E-Team selected rubber dampers and sand cushions for the construction of prototypes and physical testing in the SCARE laboratory. The necessary materials quantities were determined and acquired. The rubber dampers were installed between small concrete panels for even load distribution and to evaluate the constructability of the system, which required constructing a wooden form and placing reinforced concrete. Several students had practical experience from the American Society of Civil Engineer's concrete canoe competition. Specimens were produced according to American Society of Testing and Materials standards. Approximate manual calculations were created to validate test results. Scaling the specimens and designing the testing procedures considered the available load and displacement ranges of the laboratory equipment and its measurement gauges. Figure 3 shows such tire insulator, among other solutions, being tested in the laboratory.

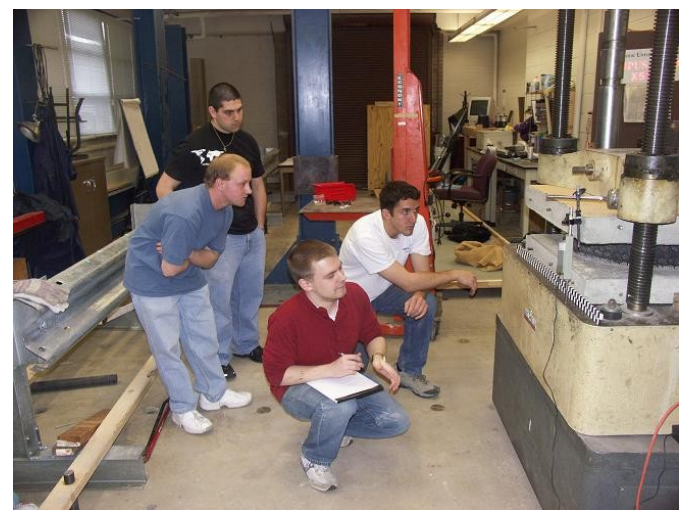

FIGURE 3

Laboratory Testing of Tire Insulator (Courtesy of Dr. Gunnar Lucko, March 2007) 


\section{Reference Structure}

To correctly assess the loads and responses by the prototype specimens of the damping systems, the E-Team developed a representative small building as a simple reference structure. Its dead and live loads and their distribution onto walls and floor segments were derived from standard building codes and representative of the anticipated structure in the developing region. It provided a useful benchmark for the actual point of structural failure in testing the specimens.

\section{Scaled Model Effects}

An interesting challenge for the E-Team lay in translating a life-size damping design into a scaled solution for testing. Scaled models are subject to similitude requirements so that they react to the loading conditions in equivalence of the actual structure for a phenomenon of interest ${ }^{56}$. Scaling yields vexing results, because length, area, and volume all scale with a different exponent and therefore e.g. a model of 1/10 scale in its exterior length dimensions will only have $1 / 100$ of its original area and 1/1000 of the weight unless material properties are adjusted. The ETeam therefore reviewed relevant literature on modeling and found that the size of the testing equipment allowed full-scale prototype specimens, which thus allowed realistic observations.

\section{Rubber Damper}

A rubber damping system is an inexpensive approach for protecting dwelling-sized structures from the potentially damaging effects of seismic activity. This design exploits its natural shockabsorbing attribute, is feasible due to the wide and inexpensive availability of rubber tires, and potentially reduces disposal in landfills. The E-Team fabricated a specimen of a rubber damper that was sandwiched between concrete and tested it under various loading scenarios that were found to more than satisfy the desired performance from the reference structure.

\section{Assessment Travel}

In January of 2008, the E-Team undertook their first trip to the host community of Santa Clara in the Usulután department of southeastern El Salvador, an approximately 90 minute drive from the airport. Santa Clara is located between several non-active volcanoes in a very rural coastal region of high seismic hazard. The village has approximately 3,200 inhabitants, many of who live in adobe buildings with loosely laid tile or metal roofs amidst fields of sugar cane on the volcanic soil. Most dwellings are not electrified. Typical transportation is on foot and by ox cart, rarely by pickup truck or bus. The travel by the E-Team followed earlier visits by several affiliated public health and construction professionals from an EWB project of a water distribution system with several miles of pipe, valves, a pump, and a large tank with a chlorination system that is fed from an existing well. This project benefited immensely from these personal contacts and their experiences but nonetheless required several months of planning by the students in the E-Team.

The following representative list provides an impression of the comprehensive work performed entirely by the students, who thus gained valuable leadership and organizational experience: Organizing bus and flights, travel insurance, and local accommodation, distributing the EWB emergency evacuation plan, providing immunization and visa information, obtaining 
approval from CUA's general counsel, writing and translating an introduction letter to the development board and other in-country contacts, hiring a bus driver, cook, and night guard, purchasing camping cots, mosquito nets and spray, walkie-talkies, first aid kit, construction dictionaries, and host gifts, preparing packing and food supply lists, writing soils testing and surveying field manuals with advice from the respective faculty, packing surveying equipment as per airline policies, and developing a daily agenda around the mid-day heat and early nightfall during the tropical dry season. The students also organized a visit to the earthquake research center in the capital city of San Salvador and to several local buildings, including adobe, brick, and concrete structures, which had been damaged in the major earthquake of 2001. Several of these items involved feedback from the community representatives through the Peace Corps volunteer as well as practical experience on the local circumstances from the volunteer herself.

Field work included digging several test pits to examine the soil layers and determine their properties to help design the foundation system and ensure the longevity of the future structure. Several manual testing methods and a penetrometer and shear test device were prepared and detailed for use in the field with detailed instruction sheets to determine the thicknesses, classifications, and mechanical properties of the different soil layers in situ, as shipping actual soil samples to external laboratories was prohibitive due to costs and customs restrictions.

A surveying transit, Philadelphia rod, and measuring tapes were transported and used for a detailed topographical map of the planned site, as available maps did not provide sufficient detail. Students practiced their use during a regular surveying workshop before the departure.

\section{Community Involvement}

The community and its representatives were involved in many ways before, during, and after the E-Team's stay in Santa Clara. For month before the travel the students, faculty, and professionals communicated electronically with the representatives of ADESCO, the community development board in Santa Clara, through the Peace Corps volunteer to establish and grow the partnership, obtain important information to plan the travel, stay, and follow-up, including logistics of transportation, housing, food, and to plan several meetings with community at large as well as the development board. The E-Team was accompanied every day by one or several representatives of the local development board. Large opening and closing meetings introduced the project to the community. The local Peace Corps volunteer assisted the E-Team in hosting a village festival with a soccer game and two piñatas for the children to express its gratitude for the community's hospitality. The community incurred no costs from this project. All transportation costs for shuttle, flights, and the hired bus, food, salaries for the hired cook and night guard, and later all construction materials, which were purchased locally, were paid from the NCIIA grant.

The development board and community volunteers assisted the E-Team in numerous ways, including providing accommodation free of charge, answering the many questions throughout the project duration, explaining needs and customs of the community, organizing the community gatherings, acting as interpreters, serving as guides on the rural paths, and digging test pits with the students for exploring the actual local soil conditions. They also participated in assessing the tank site, determining the route of the water distribution system, and building the prototype of a gray water soakage pit and a length of pipe segment under the parallel EWB project in the same community. Figure 4 shows a meeting of the E-Team with community representatives during the assessment travel and Figure 5 shows the E-Team performing surveying under field conditions. 


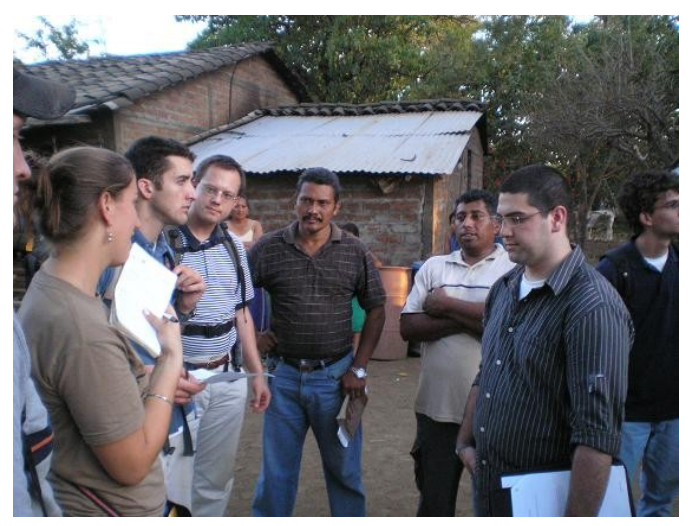

FIGURE 4

E-Team Meeting with Community

Representatives (Courtesy of Evan A. Heisman, JANUARY 2008)



FIGURE 5

Surveying Under Field Conditions (Courtesy of Dr. GunNar Lucko, January 2008)

\section{Building Description}

The E-Team dedicated several sessions to develop the architectural design based on its previously gathered insights and equipped with the first-hand knowledge from the assessment travel that included witnessing traditional construction methods and hearing descriptions of the community representatives as to their needs, i.e. functional requirements, room sizes and their arrangement, orientation on the available plot of land, and type of structural system. A professional architect, who was a member of the EWB professional chapter and had visited the host community on a prior service trip, was invited to participate in the design sessions and provide valuable advice. Afterward, the E-Team determined the required size of structural members and reinforcement with the International Building Code and prepared a quantity takeoff and cost estimate, ensuring that all used materials were locally available. All plans and calculations were reviewed by licensed professionals and approved by the EWB administration. The progress was shared in frequent electronic messages with the Peace Corps volunteer to give updates to the community, which also provided clarification and guidance for the design work.

A change that the E-Team made after the assessment travel in January 2008 was to design the structure as a health clinic to serve the entire community and not provide just one earthquakeresistant residence. Its services by resident health promoters and traveling nurses will be more basic than a hospital ${ }^{57}$, but directly address a critical need, as the inhabitants, especially children, exhibit a high level of respiratory and water-born illnesses and lack access to any outpatient or health education services within the village. The community's main concern was the insufficient access to healthcare and sanitary facilities, which the development board emphatically shared with the E-Team. Personal visitations by the E-Team with several families in the community provided evidence of these inadequate facilities first-hand and left a deep and lasting impression on all participants. The change from a single residence to a health clinic was supported by substantial work that the EWB professional chapter had been performing in a collaboration with the School of Public Health and Health Services at George Washington University to improve sanitation and public health education to prevent gastrointestinal diseases in the host community. 
The final design of the health clinic is shown in Figure 6, a floor plan from the complete set of drawings that were created by the students along with structural calculations. These were reviewed, approved by EWB, and translated into Spanish for use by the community and E-Team.

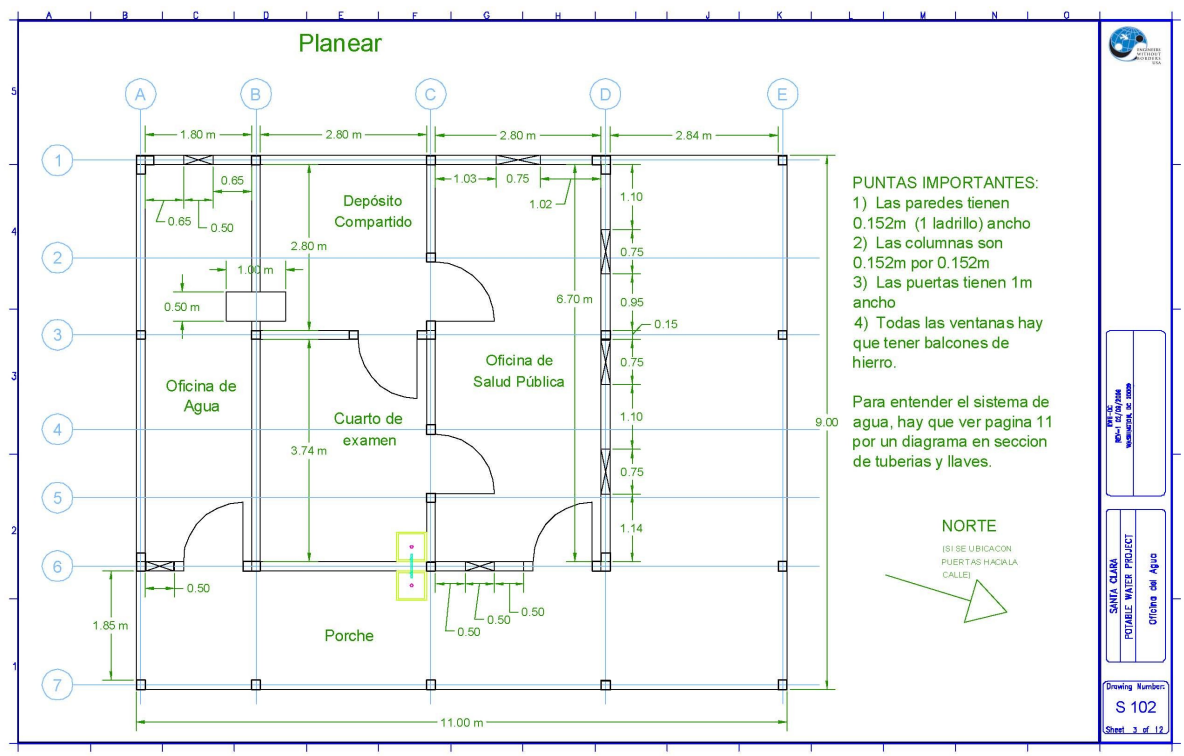

FIGURE 6

Health Clinic Final Design (February 2009)

It has a shaded porch $\left(43 \mathrm{~m}^{2}\right)$ as a waiting area, which can also be used for community meetings and four rooms: An entrance area that also is office space for three public health promoters $\left(19.6 \mathrm{~m}^{2}\right)$. The enclosed examination room $\left(10.5 \mathrm{~m}^{2}\right)$ is without window or outside door for privacy. It has a sink whose water pipe also serves the porch but can be shut off from inside. At the back of the building is a storage room for medical supplies and files $\left(7.8 \mathrm{~m}^{2}\right)$ that is also without window for security. A special feature is an interior double built-in concrete safe with steel door to hold cash, which also serves the adjacent, but physically separate office and storage room $\left(12 \mathrm{~m}^{2}\right)$ for the future water distribution system, which the EWB chapter designs in a parallel project. It is almost $7 \mathrm{~m}$ long so that a wall rack can hold replacement pipes. Security concerns (i.e. theft) described by the development board to the E-Team led to (a) choosing a roof cover of corrugated metal, (b) installing a decorative metal gridwork across all windows that is typical in this region, and (b) limiting access through one exterior metal door per functional area.

\section{IMPLEMENTATION TraVEL}

The second trip by the E-Team built heavily on the knowledge and experiences from the first and used the same preparations and travel arrangements. The trip agenda was defined by constructing the foundations with rubber dampers of the health clinic building, which is currently (Summer 2009) being completed by community volunteers using familiar construction techniques that are all performed manually, including excavation, assembling wooden formwork, cutting and bending reinforcement, tying reinforcement in mats and cages, and mixing and placing concrete. 
Figure 7 gives an overview of the site with the layout of the trenches for installing footings and Figure 8 shows community volunteers completing masonry after the implementation travel.

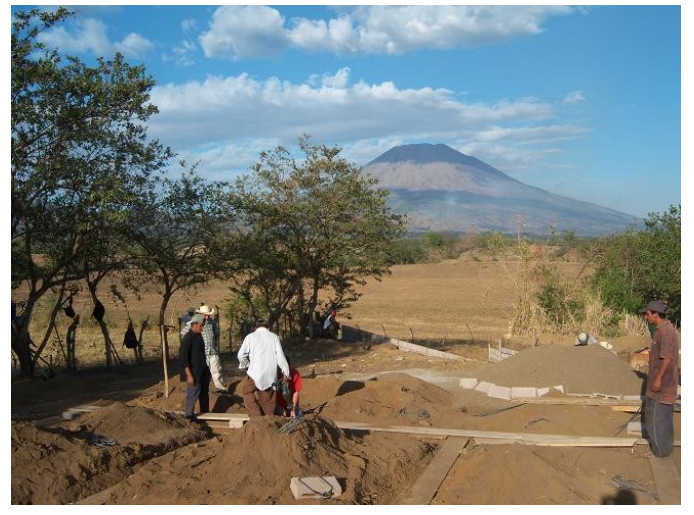

FIGURE 7

Overview of Site During Construction (Courtesy of Erica C. Gonzalez, March 2009)

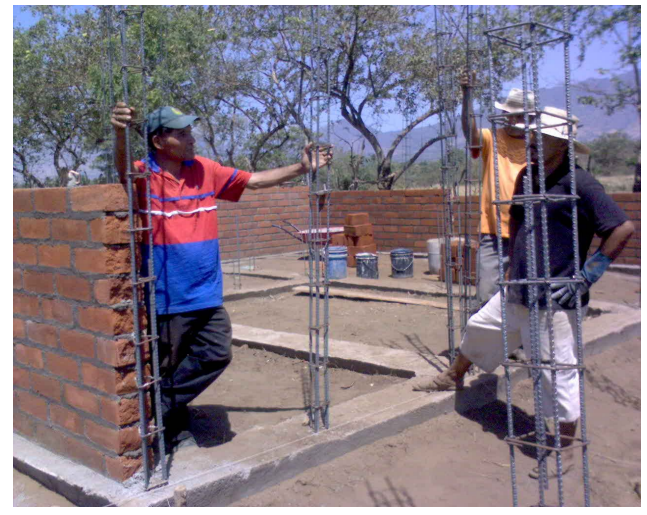

FIGURE 8

Community Volunteers Performing Masonry Work (Courtesy of Emily M. Putzer, March 2009)

The structural system consists of reinforced concrete columns with brick masonry infill, interconnected by four (!) bond beams at heights of $1.25 \mathrm{~m}, 2 \mathrm{~m}, 2.75 \mathrm{~m}$, and also along the ridgeline as shown in Figure 9 that support a gable roof that is covered with corrugated metal. The community is very familiar with building such structures. Rubber damper pads were cut from used tires and were mounted onto a grid of square spread footings to carry the strip footings underneath all walls, except for the smaller spread footings along the perimeter of the porch.



\section{FIGURE 9}

Health Clinic Nearing Completion (Courtesy of Emily M. Putzer, May 2009) 


\section{Community Involvement}

The E-Team's implementation travel occurred during the school year to avoid the rainy season in summer and was again limited to one week in the host community. Again, an intense amount of communication about trip planning, its trip agenda, and various construction management issues occurred. The E-Team especially wished to be present during construction of the novel elements of the structure, the dampers and the foundation around them. The E-Team therefore consulted with the development board of the village through the Peace Corps volunteer to have the final chosen site stripped of undergrowth and begin trench excavation before arrival. During the trip, community volunteers and the E-Team then worked side-by-side on the remaining excavation, erecting wooden formwork with simple carpentry tools, assembling wire mesh reinforcement, and building the 3D reinforcement cages for the spread footings and their rubber dampers. Interestingly, the students gained practical skills from the inventive local volunteers, e.g. bending reinforcement with leverage, who in turn were introduced to the first seismic dampers under a building type that was familiar in their village. Concrete was mixed manually with shovels that the inhabitants owned. The community meetings again punctuated the duration of the stay. Since then the building has been substantially completed and will be opened in the near future with the tireless work of many volunteers who donated their labor. EWB advocates such substantial local involvement so that a community has an owner's stake and uses the project. The EWB chapter is continuing with their service outreach on the new water distribution system for Santa Clara.

\section{Student Evaluations and Reflections}

All member of the E-Team were asked for improvement suggestions in a survey questionnaire $a$ priori, mid-semester, and a posteriori using both structured and open-ended questions. This feedback items included improving timing and duration of class sessions, adding more schedule planning, and increasing the students' involvement in communicating with the host community, which was still implemented during each ongoing semester so that the students and the project benefited. Course and instructor evaluation criteria were measured by 9 questions with a 7-point Likert scale, including 1 . the ability to apply the knowledge of mathematics, science, and engineering and gaining the ability to identify, formulate, and solve engineering problems (6.6); 2. the ability to design and conduct experiments and to analyze and interpret data or the ability to design and system, component, or process and to use modern engineering tools (6.5); 3 . the ability to function on multi-disciplinary teams and gaining an understanding of professional and ethical responsibility, and gaining an ability to communicate effectively (6.6); 4. gaining the broad education necessary to understand the impact of engineering solutions in the global and societal context and gaining a knowledge of contemporary issues (6.9); 5. instructor is receptive to questions both in class and outside of class $(6.5)$; 6. instructor emphasizes the fundamentals (6.4); 7. instructor clarifies the text material and offers his/her own perspective (6.9); 8 . instructor illustrates the material with well-designed examples and/or class projects (6.8); and 9. gaining a recognition of the need for and an ability to engage in life-long learning (6.9). Values are averages over three semesters that have been weighted by the respective number of students.

Presented work was critiqued constructively to elevate the attained level of knowledge and understanding. Students submitted regular evaluations to the university with the following results: The course sequence received a 9.1 overall average on a scale where 10 is best, which exceed the averages of the university (7.9) and department (8.0) in the same period. Students also 
provided written comments on their learning experience that provide an unedited reflection in their own voices and may more tangible than their numerical scores from the formal evaluation:

I am so refreshed to see the implementation of this course into our program. The course has the immediate scholastic benefits similar to a capstone design course where students pool their knowledge of simple engineering components to solve complex engineering problems. The key difference being that these are real projects and real problems. There is now an outside drive of compassion and satisfactions which motivates students to learn. The structuring of the course is also crucial to its success. For students to have any sort of control in a course it automatically locks their interest in their course. The sense of involvement and responsibility ensure active participation.

Senior, Civil Engineering

I personally learned a lot from this way of teaching, not only about the work we accomplished but about myself too as a student. It was easier to comprehend what we were doing because we went at our own pace and there was not a ton of information thrown at us at one time that we must fully know before the next class. It is nice to know that soon we will be able to put what we learned to the test in the real world and we will be helping many people at the same time. I learned how to think more critically and outside of the box and to better voice my opinion. Finally knowing that the professors wish to be able to consider their students as colleagues made the environment feel less like a classroom setting.

Junior, Civil Engineering

This class gives students the liberty to help structure the development of the course itself, which pushes students to participate more actively, and to be more independent and proactive in the undertaking of the course activities. I enjoyed the experience of collectively setting course objectives with both classmates and professors and the freedom to determine to a certain extent the length and quality of class assignments; however, depending on the student, the liberty to determine certain parameters on the amount and depth of class assignments can lead to work overload. Overall, I think this type of teaching approach increases the productivity and performance of students because they themselves are setting the goals to be accomplished, which in many cases takes away any feelings of boredom or perceptions of feeling dragged to complete imposed tasks.

Graduate Student, Civil Engineering

\section{Conclusions and Recommendations}

This paper has described a student-centered learning environment that was applied to service outreach in a close collaboration with EWB. The urgent need for more earthquake-resistant structures was established. The theoretical background of student-centered learning, its relationship with learning styles and the taxonomy, and low-cost damping systems were described. Major educational elements were listed in a chronological order, including a comprehensive literature review, laboratory testing, and design, plus supporting elements.

Student members planned the two trips to the host community in El Salvador. Volunteers from the community were involved during development and construction. Their participation 
ensured the acceptance of the facility and was essential for successful completion. The small health clinic was designed based on the needs for earthquake protection in that developing region combined with the lack of basic healthcare in the community of which the E-Team became aware. Its modest scale was deliberately set to be achievable by the members and the community within the available funding and timeframe, while addressing urgent two basic and urgent needs. The solution that was implemented - rubber dampers made of used tires - is technically feasible, inexpensive, and advantageous in terms of recycling. While the structural system did not employ traditional building materials (e.g. adobe with natural fibers) due to concerns over their longevity in the tropical climate and seismic performance (e.g. clay tiles), the solution was entirely within the technical capabilities and building practices of the host community. It already had several buildings with reinforced concrete frame and masonry infill, albeit none with a seismic damping system. Its cost versus the literarily free adobe is at least partially offset by longevity and safety.

Student feedback indicated an exceptionally favorable reception of the student-centered approach of this project, which has been featured in university publications and was presented to the campus public. Students noted the non-traditional and more holistic learning that it afforded them. Inspired by the enriching experience from this project, the first author is planning to embark on a year of service work in Honduras. Transferring the experiences from this studentcentered approach to further work at CUA or to other institutions is possible but requires comprehensive planning and a source of funding. This project spanned over three years under a grant that provided for travel and materials and may thus be difficult to replicate at the same scale. However, other basic needs exist in developing regions for which solutions in sustainable, low-cost technology can be explored. Examples could be solar water cookers and sand filters for potable water. Investigating ways to use the inherent beneficial properties of natural building materials, e.g. adobe, combined with engineering solutions to increase their resilience to seismic events and erosion is another avenue to continue the "academic trinity" of research, teaching, and service that this project brought to the student participants and the host community to train globally aware and socially engaged young engineers.

\section{AcKnowledgment}

The authors gratefully acknowledge support by grant number 3090-05 of the National Collegiate Inventors and Innovators Alliance (NCIIA) for this project. Any opinions, findings, conclusions, or recommendations expressed in this publication are those of the authors and do not necessarily reflect the views of NCIIA.

The authors wish to especially thank Dr. Panagiotis Tsopelas, earthquake expert and coinvestigator of the corresponding author, Dr. George P. Mavroeidis for structural advice, Mr. Alexander R. Higbee for architectural advice, Dr. Poul V. Lade for his geotechnical advice, Dr. Dennis F. McCahill for surveying advice, the students who enrolled in the CE 434 and CE 435 courses in the past years and traveled to El Salvador, Dr. John A. Judge, founding advisor of the EWB student chapter and its members, the EWB professional chapter for their practical advice and support in preparing the two trips, Ms. Emily M. Putzer, Peace Corps volunteer, and last not least the inhabitants and development board of Santa Clara in El Salvador for their kind and generous hospitality during our travels. 
International Journal for Service Learning in Engineering

Vol. 5, No. 1, pp. 189-209, Spring 2010

ISSN 1555-9033

\section{REFERENCES}

${ }^{1}$ Kelly, W. E. 2008. General education for civil engineers: Sustainable development. Journal of Professional Issues in Engineering Education and Practice 134(1): 75-83.

${ }^{2}$ Liu, B-.Y., Miao, S., Le, Ye, L.-Y., and Xiao, M.-L. 2006. Damage of village buildings in recent Yunnan earthquakes. Paper No. 266, Proceedings of the $4^{\text {th }}$ International Conference on Earthquake Engineering, October 12-13, 2006, Taipei, Taiwan: National Center for Research on Earthquake Engineering.

${ }^{3}$ Anon. 2005. North Kashmir earthquake - reconnaissance survey. Indian Concrete Journal 79(11): 17-18.

${ }^{4}$ Carbajal, F., Ruiz, G., and Schexnayder, C. J. 2005. Quincha construction in Perú. Practice Periodical on Structural Design and Construction 10(1): 56-62.

${ }^{5}$ Durkin, M. E., and Hopkins, J. 1987. The San Salvador earthquake of October 10, 1986 - architecture and urban planning. Earthquake Spectra 3(3): 609-620.

${ }^{6}$ Lara, M. A. 1987. The San Salvador earthquake of October 10, 1986 - history of construction practices in San Salvador. Earthquake Spectra 3(3): 491-496.

${ }^{7}$ Day, R. W. 1993. Performance of historic adobe structure. Journal of Performance of Constructed Facilities 7(3): 164-169.

${ }^{8}$ United States Geological Survey. 2009a. Historic worldwide earthquakes collection.

$<$ http://earthquake.usgs.gov/regional/world/historical.php>, June 22, 2009.

${ }^{9}$ United States Geological Survey. 2009b. Significant earthquakes of the world collection.

$<$ http://earthquake.usgs.gov/eqcenter/eqarchives/significant $>$, June 22, 2009.

${ }^{10}$ United States Geological Survey. 2009c. Earthquakes with 1,000 or more deaths since 1900.

$<\mathrm{http} / /$ earthquake.usgs.gov/regional/world/world_deaths.php>, June 22, 2009.

${ }^{11}$ United States Geological Survey. 2010. Magnitude 9.1 - Off the west coast of northern Sumatra.

$<$ http://earthquake.usgs.gov/earthquakes/eqinthenews/2004/us2004slav/\#summary>, March 25, 2010.

${ }^{12}$ Sengupta, A. K. 2006. Development of a handbook on seismic retrofit of buildings in India. Paper No. 316, Proceedings of the $4^{\text {th }}$ International Conference on Earthquake Engineering, October 12-13, 2006, Taipei, Taiwan: National Center for Research on Earthquake Engineering, 8 p.

${ }^{13}$ Sarkar, R. 2006. Post earthquake housing construction using low cost building materials. Paper No. 275, Proceedings of the $4^{\text {th }}$ International Conference on Earthquake Engineering, October 12-13, 2006, Taipei, Taiwan: National Center for Research on Earthquake Engineering, 8 p.

${ }^{14}$ Engineering Accreditation Commission 2009. Criteria for accrediting engineering programs. Baltimore, MD: Accreditation Board for Engineering and Technology, <http://www.abet.org/Linked\%20DocumentsUPDATE/Criteria\%20and\%20PP/E001\%2009-10\%20EAC\%20Criteria\%2012-01-08.pdf>, June 18, 2009.

${ }^{15}$ Abudayyeh, O. Y., Russell, J. S., Johnston, D. W., and Rowings, J. E. 2000. Construction engineering and management undergraduate education. Journal of Construction Engineering and Management 126(3): 169-175.

${ }^{16}$ Lucko, G. 2006. Student-centered learning environment during undergraduate education in construction engineering and management - developing a construction consulting project. Proceedings of the ASCE and CIB $2^{\text {nd }}$ Specialty Conference on Leadership and Management in Construction, May 4-6, 2006, Reston, VA: American Society of Civil Engineers: 341-349.

${ }^{17}$ Barr, R. B., and Tagg, J. 1995. From teaching to learning: A new paradigm for undergraduate education. Change 27(6): 13-25.

${ }^{18}$ Williams, K., and Pender, G. 2002. Problem-based learning approach to construction management teaching. Journal of Professional Issues in Engineering Education and Practice 128(1): 19-24.

${ }^{19}$ Cannon, R. 2000. Guide to support the implementation of the learning and teaching plan year 2000. Adelaide, Australia: The University of Adelaide, Centre for Learning and Professional Development.

${ }^{20}$ Pearce, J. M. 2006. Service learning in engineering and science for sustainable development. International Journal for Service Learning in Engineering 1(1): 1-4.

${ }^{21}$ Duffy, J., Moeller, W., Kazmer, D., Crespo, V., Barrington, L., Barry, C., and West, C. 2008. Service-learning project in core undergraduate engineering courses. International Journal for Service Learning in Engineering 3(2): $18-41$.

${ }^{22}$ Amadei, B., Sandekian, R., Summers, R. S., and Bielefeldt, A. 2006. Engineering for developing communities: Integrating education, research and development, and service/outreach into engineering education. Proceedings of the 2006 ASEE Annual Conference and Exposition, ed. Davis, W. D., Chicago, IL, June 18-21, 2006, Washington, DC: American Society for Engineering Education: 9 p. 
International Journal for Service Learning in Engineering

Vol. 5, No. 1, pp. 189-209, Spring 2010

ISSN 1555-9033

${ }^{23}$ Sheppard, S. D., Pellegrino, J. W., and Olds, B. M. 2008. On becoming a $21^{\text {st }}$ century engineer. Journal of Engineering Education 97(3): 231-234.

${ }^{24}$ Bloom, B. S. 1984. Taxonomy of educational objectives. Boston, MA: Allyn and Bacon

${ }^{25}$ Lucko, G. 2006. Student-centered learning environment during undergraduate education in construction engineering and management - developing a construction consulting project. Proceedings of the ASCE and CIB $2^{\text {nd }}$ Specialty Conference on Leadership and Management in Construction, May 4-6, 2006, Reston, VA: American Society of Civil Engineers: 341-349.

${ }^{26}$ Bloom, B. S. 1984. Taxonomy of educational objectives. Boston, MA: Allyn and Bacon

${ }^{27}$ Felder, R. M., and Brent, R. 2005. Understanding student differences. Journal of Engineering Education 94(1): 57-72.

${ }^{28}$ Felder, R. M., and Silverman, L. K. 1988. Learning and teaching styles in engineering education. Journal of Engineering Education 78(7): 674-681, with new author's preface.

${ }^{29}$ Felder, R. M., and Silverman, L. K. 1988. Learning and teaching styles in engineering education. Journal of Engineering Education 78(7): 674-681, with new author's preface.

${ }^{30}$ National Collegiate Inventors and Innovators Alliance. 2009. Advanced E-Team grants.

$<$ http://nciia.org/grants/eteam $>$, June 22, 2009.

${ }^{31}$ Maslow, A. H. 1970. Motivation and personality, $2^{\text {nd }}$ ed., Harper and Row, New York, NY.

${ }^{32}$ Fogler, H. S., and LeBlanc, S. E. 1994. Strategies for creative problem solving. Upper Saddle River, NJ: Prentice Hall.

${ }^{33}$ Fogler, H. S., and LeBlanc, S. E. 1994. Strategies for creative problem solving. Upper Saddle River, NJ: Prentice Hall.

${ }^{34}$ McGarvey, K., Biggs, M., Hill, J., Panko, M., Bacher, N., Sukumaran, B. 2009. Engineering innovators without borders: Developing entrepreneurial opportunities for the developing World through engineering redesign. International Journal for Service Learning in Engineering 4(1): 48-61.

${ }^{35}$ Turer, A., and Gölalmış, M. 2008. Scrap tire ring as a low-cost post-tensioning material for masonry strengthening. Materials and Structures 41(8): 1345-1361.

35 Turer, A. 2006. Turkey: Scrap tires saving homes. Development Marketplace website, $<$ http://web.worldbank.org/WBSITE/EXTERNAL/OPPORTUNITIES/GRANTS/DEVMARKETPLACE/0,,content MDK:20247631 pagePK:180686 piPK:180184 theSitePK:205098,00.html>, June 22, 2009.

37 Turer, A., Korkmaz, S. Z., and Korkmaz, H. H. 2006. Performance improvement studies of masonry houses using elastic post-tensioning straps. Earthquake Engineering and Structural Dynamics 36(5): 683-705.

${ }^{38}$ Özden, B. 2006. Low-cost seismic base isolation using scrap tire pads (STP). Thesis, Ankara, Turkey: Middle East Technical University, The Graduate School of Natural and Applied Sciences.

${ }^{39}$ Kelly, J. M. 2002. Seismic isolation systems for developing countries. Earthquake Spectra 18(3): 385-406.

${ }^{40}$ Bauer, D., Baldwin, J., and Ellwood, K. 2005. Correlation of rubber properties between field aged tires and laboratory aged tires. Rubber Chemistry and Technology 78(5): 777-792.

${ }^{41}$ Tsang, H.-H. 2007. Seismic isolation by rubber-soil mixtures for developing countries. Earthquake Engineering and Structural Dynamics 37(2): 283-303.

${ }^{42}$ Anantha Narayan, C. K., Arun Kumar, S., and Maharajan, S. 2003. Earthquake resistant design using tyres as dampers. Submitted in partial fulfillment $[\mathrm{sic}]$ for the award of degree of bachelor of engineering, Chennai, India: University of Madras.

${ }^{43}$ Nguyen, T. L. 1996. Utilization of used tyres in civil engineering - the pneusol 'tyresoil'. Environmental Geotechnics: 809-814.

${ }^{44}$ Anantha Narayan, C. K., Arun Kumar, S, and Maharajan, S. 2003. Earthquake resistant design using tyres as dampers. Submitted in partial fulfillment [sic] for the award of degree of bachelor of engineering, Chennai, India: University of Madras.

${ }^{45}$ Overly, J. 2008. Old tires find new role in protecting airport: John Wayne Airport might use 30,000 old tires to protect baggage-screening room during an adjacent demolition. The Orange County Register, February 11, 2008, $<$ http://www.ocregister.com/news/tires-parking-room-1977849-baggage-garage>, June 22, 2009.

${ }^{46}$ Dou, Y.-M., Liu, X., Zhao, S., and Liu, Z. 2005. Experimental study of isolating properties of sand cushion. Journal of Building Structures 26(1): 125-128.

${ }^{47}$ Niu, Z.-R. 2001. Application of the reinforced sand-stone cushion in foundation consolidation. Rock and Soil Mechanics 22(1): 195-198. 
${ }^{48}$ Weng, S., and Ma, S.-D. 2001. Effect of the geotextile-reinforced sand cushion on the deformation and stability of the foundation under a embankment. Rock and Soil Mechanics 22(1): 42-46.

${ }^{49}$ Lin, X.-L., Zhou, L.-M., Wu, J.-D., and Wei, J.-L. 2000. Application of geotextile-reinforced sand cushion in ground treatment of buildings. Rock and Soil Mechanics 21(3): 252-255.

${ }^{50}$ Sonoda, Y., Satoh, H., Ishikawa, N., and Ohta, T. 1994. Fundamental study on impact response of sand cushion by distinct element method. Proceedings of Japan Society of Civil Engineers 483(1-26): 51-60.

${ }^{51}$ Ertürk, N., and Sungay, B. 2005. Non-structural mitigation against earthquake: A case study of Istanbul museums. Proceedings of the $200519^{\text {th }}$ Annual Meeting of the Society for the Preservation of Natural History Collections (SPNHC), Museum SOS: Strategies for Emergency Response \& Salvage, May 11-16, 2004, New York, NY: American Museum of Natural History $<\mathrm{http}: / /$ museum-sos.org/htm/strat_non structural_mitigation.htm $>$, June 22, 2009.

${ }^{52}$ Yegian, M. K., and Catan, M. 2004. Soil isolation for seismic protection using a smooth synthetic liner. Journal of Geotechnical and Geoenvironmental Engineering 130(11): 1131-1139.

${ }^{53}$ Islam, M. S., Honda, K., and Iwashita, K. 2006. Improvement of seismic resistance of adobe structures. Proceedings of the $20061^{\text {st }}$ European Conference on Earthquake Engineering and Seismology, eds. Koller, M., Giardini, D., Geneva, Switzerland, September 3-6, 2006, Istanbul, Turkey: European Association for Earthquake Engineering.

${ }^{54}$ Carbajal, F., Ruiz, G., and Schexnayder, C. J. 2005. Quincha construction in Perú. Practice Periodical on Structural Design and Construction 10(1): 56-62.

${ }^{55}$ Kelly, J. M. 2002. Seismic isolation systems for developing countries. Earthquake Spectra 18(3): 385-406.

${ }^{56}$ Harris, H. G., and Sabnis, G. M. 2006. Structural modeling and experimental techniques. $2^{\text {nd }}$ ed., Boca Raton, FL: CRC Press.

${ }^{57}$ Sherif, A. H. 1999. Hospitals of developing countries: Design and construction economics. Journal of Architectural Engineering 5(3): 74-81. 